\title{
Implication of Brown Envelope Syndrome on Hate Speech and Fake News in Nigerian Media
}

\author{
Lukman Adegboyega Abioye PhD \\ Department of Mass Communication, Lead City University, Ibadan, Nigeria \\ Email: gboyegaabioye@yahoo.com.
}

Tel; +2348023318934

Keywords: Journalism, Hate speech, Fake news, Yellow Journalism, Gratifications.

\begin{abstract}
This study discusses brown envelope syndrome as it is used by some journalists to promote hate speech and fake news with negative effect on the practice of journalism in Nigeria. Various reasons are advanced from the study to show why the menace of brown envelope syndrome, hate speech and fake news persists in Nigeria and the solutions for addressing the problems are also explored. Two theories are used in putting the study in proper perspectives. The theories are Agenda Setting and Dependency Theory. The two theories recognize the role of mass media in mobilizing, educating and entertaining the public on vital, social, economic and political issues. The study recognizes the role of journalists in promoting hate speech and fake news in order to advance the interest of certain political class. Hate speech and fake news consist of lies and vulgar languages against a particular section of the society. The study found out that journalists use both print and electronic media to spread fake news and hate speech which however has significant effect on the political development of the country. The study recognizes that poor remuneration, inadequate training, job insecurity as well as general economic downturn in Nigeria have been responsible for brown envelope syndrome. Media researchers are of the opinion that proprietors of media houses, and the government should take the welfare of journalists very seriously if journalistic code of ethics and practice would be applied on any erring journalist. The study recommends regular training and staff motivation as necessary for eradicating the menace of brown envelope syndrome, fake news and hate speech among practicing journalists in Nigeria. Appropriate legislation must be put in place by the legislatures to discourage hate speech and fake news in the country. Erring journalists and the media houses that they represents must be sanctioned accordingly to serve as deterrent to others.
\end{abstract}

\section{Introduction}

Brown envelope journalism in Nigeria is a practice whereby monetary inducement is given to journalists to make them write a positive story or kill a negative story. The name is derived from cash inducements hidden in brown envelopes and given to journalists during press briefs. Idowu (2010) in "IBB, Sahara Reporters and the Press" decried the growing practice of journalists receiving money to publish stories and explained the appeal of corruption.

Idowu (2016:111-112) remarks that

too many things are taken for granted in Nigerian journalism, that the strange has become the accepted. Many journalists see nothing wrong in accepting money to publish stories. Take for example, the age long practice of facility tours where Governor 'A' or Company ' $B$ ' invites the media and pays for the journalist's passage and accommodation in expectation of coverage. While the facilitators see it as opening doors to better media access, the journalists sadly find such trips augmenting if not guaranteeing their pay for the month. In their thinking, new contacts have been cultivated, new horizons are waiting to be explored. The result is a pattern of tainted reporting far from the envisaged professionally processed news served to the public. Receiving monetary gifts in the name of transport reimbursement compromises the integrity of news no matter how popular it is. 
Alongside the 'brown envelope syndrome' variable in this study is the 'hate speech' variable. United Nations Committee in Ojebode (2018) describes hate speech to include but not limited to the under-listed:

a) All dissemination of ideas based on racial and ethnic superiority or hatred by whatever means;

b) Incitement to hatred, contempt or discrimination against members of a group on grounds of their race, colour, national or ethnic origin;

c) Threats of incitement to violence against members of a group on grounds (b) above and

d) Expression of insults, ridicule or slander of persons or groups or justification of hatred, contempt or dissemination on the grounds in (b) above when it clearly amounts to incitement to hatred or discrimination.

The description above is one that clearly explains hate speech. It is however important to state that this broad definition or description misses is the role of religion as a basis for hate speech (Ojebode, 2018) in Nigeria. One cannot explicitly discuss hate speech in Nigeria without mentioning the Nigerian media. The Nigerian media play a pivotal role around which socioeconomic, political, health, education and cultural activities revolve, thereby making governments at all levels depend largely on the support of the media in propagating their policies and programmes for the people. No doubt, mass media have been responsible for the rise in the social empowerment of citizens of modern societies. However, the media have shifted generally from the traditional roles to more vocationally relevant objectives, which embrace the promotion of people's interest in society and in all spheres of life.

The media's important role was given credence by Miabore (2010) as cited by Adisa et al (2017) when they opine that mass media have become an important force in society not only as a means for the expression of ideas but also as a social force to be reckoned with and a vehicle for mobilization. In a similar opinion, Geibner (1990) posits that mass media provide the broadest common currencies of public interaction in a society; therefore, communication through the mass media becomes one of the important and basic social processes in any society.

In support of Baran (2007) and Geibner (1990), Adesanoye (1990) also remarks that mass media perform a number of functions such as disseminating information, educating people, setting agenda, promoting culture and acting as a watchdog, etc. without which the society would be in chaos and in complete darkness. By providing people with information, the mass media according to Lasswell (1948) as quoted by Ndolo (2005) perform the duty of keeping surveillance on society, correlate the environment and transmit social heritage from one generation to the other and entertain the public.

MacBride (1980) sees journalism as a noble profession, which demands for discipline and ethical behaviour from the practitioner. Recognizing the importance of journalism, MacBride et al (1981) note that society needs information to react knowledgeably to people's personal conditions as well as take appropriate socio-economic decisions. In developing countries like Nigeria, poverty debases human dignity and diminishes scale of honour. Love of money through gratification to influence news as opposed to editor's sense of value is the order of the day (Okoro and Ugwu 2006). These shortcomings may force journalists to engage in some unethical practices such as sensationalism, yellow journalism, hate speech, fake news, invasion of privacy and brown envelope syndrome otherwise known as gratification. These vices characterize media landscape in Nigeria, Nigeria, which may adversely affect the credibility of media reports (Okoro and Ugwu 2006).

This paper examines the prevalence of corruption in the Nigerian media for which the much talked about brown envelope merely illustrates and establishes what consequences this disorder has for the professional health of Nigerian journalism and what could be done to strengthen the capacity of the Nigerian media to play its watchdog role much more effectively. No wonder Idowu (2018) remarks that the media parades all sorts of players; from the trained to the untrained, the purpose 
driven journalists to the gate crashers, the ethical and the whimsical in its industry. The role of journalists in any society can never be over emphasized.

Journalism no doubt is a veritable tool for information dissemination, social mobilization and a means of public education and sensitization to important issues affecting the lives of the people. The vehicle through which journalists fulfill this obligation to the society is the mass media which comprise radio, television, films, books, sound recordings, newspapers, magazines, the internet, etc. The society depends on the regular content and accuracy of the mass media messages for information, opinion, entertainment, ideas, etc. Journalism serves as a mirror in the society, the gatekeeper of issues and events and as such a very important social institution.

As watchdog of the society, journalists are expected to bridge the gap between the government and the society, and thus, make government accountable to the people. Okoro and Ugwu (2006) remark that brown envelope syndrome seems to be having a devastating effect on journalistic practice in Nigeria leading to a decline in quality, value, and ethical morality among journalists. Olukotun (2016) is of the opinion that truth, accuracy, fairness, balance and objectivity are fast becoming fantasies in Nigeria's journalistic landscape because of the cankerworm called brown envelop syndrome.

However, Agbanu (2011) defines brown envelope syndrome as a situation whereby journalists demand for bribe or other forms of gratification before they cover any event or even publish stories from such event. That is why Ekeanyanwu and Obasnigwe (2012) conclude that brown envelope syndrome has become an albatross for the 21 st century Nigerian journalists. Media scholars have described brown envelope as a form of inducing writers and editors with financial gratification to influence their writings in favor of the givers.

Carrington and Nelson (2002: 226-227) remark that

\begin{abstract}
"Worsening economic pressure often pushes news organizations to seek a safe harbor which can mean turning to politicians or special interests for support. They do this however, at the expense of their editorial independence, because the rescuers rather than investing in the long-term profitability of the news concerns look for the short - term gains of owning a propaganda arm that they can commandeer into advancing their political or economic interests.
\end{abstract}

Adaba (2001) has accused professional bodies like the Nigerian Union of Journalists (NUJ) and the Nigerian Guild of Editors (NGE) and others at the helm of affairs of not adhering strictly to the ethics of the profession by giving appropriate sanctions to the erring journalists. The implication is that real news is watered down while irrelevant issues such as "alternative facts," hypes and outright lies, are given prominence. That may be the reason why Agbanu (2011) argues that monetary gifts can pressure gullible journalists into doing what the givers want and as such render the journalists incapable of being objective in their reporting of events and issues involving the people who give such gifts. Thus, the news stories produced are likened to commercial products that have been dubiously paid for by the customers, which should meet the needs for which the products are expected in favour of the giver.

Even since the 2019 general elections were concluded, the Nigerian media landscape is still filled with hate speeches and fake news being used by the politicians and religious leaders to cause disaffection and hatred in the country. Hate speech and fake news are used to discredit government policies and notable personalities in the country. The aim is to cause the general public to have apathy against the ruling class or the opposition. Hate speech is spread by the media houses in form of fake news. Most of the media houses have been accused of spreading fake news with the intent of bringing the government or opposition to disrepute. Economic and political gains have been the motive behind fake news to the extent that government is doing all what it can do to address the problem and bring the perpetrators to book. Computer manipulations have greatly increased the practice of fake news in Nigeria. There were instances where notable personalities were disfigured as if the persons were suffering from incurable diseases. Former Nigerian Petroleum Minister Deziani Madueke was an example that fits into this saga. Also, there were hundreds of pictures 
circulating on social media in the country on a daily basis which are of fake news intent. One would recall the picture of the Former Finance Minister Mrs. Kemi Adeosun, wearing NYSC uniform while welcoming a foreign leader to Nigeria several months back. There are several others of such pictures claiming or depicting inter-communal violence across the country which further inflame the existing political and social-ethnic tensions in Nigeria (Alade, 2019).

Politicians have been accused of using journalists to promote fake news so that the general public will be disenchanted against the government of the day. Fake news may be used to attack prominent individuals in government or to attack government policies and programmes. It is not only through the print media that the fake news is spread, electronic media, the internet, Whatsapp, Facebook, among others are used to spread fake news. In another example, there was the story that the Indigenous People of Biafra (IPOB), and Nnamdi Kanu, had apologized to President Muhammadu Buhari for referring to him as a terrorist among others in his radio broadcast. This turned out to be false as his lawyer, Vincent Obetta debunked the story. There was also the fake news that President Muhamadu Buhari closed down Aso Rock Villa church built by his predecessor Chief Olusegun Obasanjo, the intention was meant to cause religious disharmony in the country.

Recently, there was an audio recording by one Olivia; a genetic nurse in the United Kingdom which went viral warning Nigerians not to vote for President M. Buhari because he was sick and therefore was not fit for public office. This also turned out to be fake news. Furthermore, Minister of Information Alhaji Lai Mohammed was reported by the media to have said that the government of Nigeria had done so much in the area of agriculture especially reducing rice importation to the extent that local production had increased tremendously and rice Mills in Thailand were closing down.

It should be noted however that the media is often vilified as the originators and perpetrators of fake news and hate speeches including misrepresentation of reality to the general public. The year 2017 recorded an increase in the arrests of journalists in Nigeria many of which went down to what was related to poor reporting and fake news (Ojebode, 2018).

On a daily basis, traditional print media publish interviews and opinions of Nigerians especially politicians and religious leaders who express their warped ethnic, religious and political views that are not in tandem with rational behavior (Alade, 2019). There are rumors in the public domain that journalists are hired to write unsubstantiated reports on the policies and programmes of government with fake allegations of bribery and corruption, while members of the opposition parties have been accused of sponsoring fake news against the ruling party. Hate speech has also entered into our religious lives as religious authorities believe they are superior to each other and as such make public information that can influence their followers against their perceived enemies.

\section{Statement of the Problem}

In recent times, there are some instances where public officials were accused of making hate speeches in Nigeria. According to Fasakin et al (2017), the Kaduna State Governor, Mallam Nasir El-Rufai, was reported to have said that foreigners who would intervene in the 2019 general election would "go back in body bags." Secondly, another Governor mentioned that those who want to take power through the back door will die. In addition, President M. Buhari was reported to have said that ballot box snatchers should be shot. Such statements would be considered as hate speech and not good enough for our nascent democracy and the image of the country, where our leaders were seen as making provocative statements that could promote violence among various ethnic groups that make up the nation.

There is no gain saying that journalists play a major role in the development, unity and progress of a country like Nigeria where there is ethno-religious diversity. The traditional role of journalist in nation building is being threatened as a result of major issues that have found relevance in the practice of the profession. The issues of brown envelope syndrome, hate speech and fake news have been a cog in the wheel of progress in the practice of journalism in Nigeria. The political class have been accused of using monetary power to influence news reportage so as to cause violence, political 
upheaval and disunity among the different ethnic groups in Nigeria, using journalists as instruments to promote fake news and hate speech after inducing them with monetary gratification.

This paper will analyse the role of brown envelope syndrome in promoting hate speech and fake news among the media practitioners in the print and electronic media in Nigeria. This study is thus aimed at examining the implication of the brown envelope syndrome on hate speech and fake news as found in the practice of journalism in Nigeria, and its attendant consequences on the role of the mass media as agents of information dissemination and watchdog of the executive arm of government among others.

\section{Research Questions and Contributions to Knowledge}

1. What are the causes of brown envelope syndrome in Nigeria?

2. What are the perceptions of the journalists on impact of brown envelope syndrome on journalistic practice in Nigeria?

3. What are the impacts of brown envelope syndrome on hate speech and fake news?

\section{Theoretical Framework and Literature Review}

This study used a combination of Dependency and Agenda setting theories as theoretical framework upon which this study is based. Mass Media is communication - whether written, broadcast or spoken - that reaches a large audience. This includes television, radio, advertising, movies, the Internet, newspaper, magazines, and so on and is a significant force in modern culture and society particularly in Nigeria.

\section{Agenda Setting Theory}

Agenda setting theory which was propounded by Maxwell McCombs and Donald Shaw in 1972 is the creation of public awareness and concern of salient issues by the media.

The basic assumptions of Agenda Setting Theory are that:

i. The press and the media do not reflect reality; they filter and shape it.

ii. Media concentration on a few issues and subjects leads to the public to perceive those issues as more important than other issues.

Folarin (2005) states that agenda setting implies that the mass media pre-determine what issues are regarded as important at a given time in a given society and that agenda setting has the under listed elements

- The quantities or frequency of reporting

- Prominence given to the reports through headlines display, pictures and layouts in newspapers, magazines, films, graphics or timing on radio and television.

- Cumulative media-specific effects over time.

Recently, the agenda - setting theory has been extended to deal not only with which issues that are emphasized in the media, but also how these issues are presented (Folarin 2005). According to McCombs (1992) every agenda basically consists of a set of objects and each of these objects has a set of attributes which include the aspect that people think about when they think about the issue. McCombs and Shaw (1993) succinctly put agenda setting as a process that can affect both what to think and how to think about it and that it is through the media that:

\section{"Audience not only learn about public issues and other matters but also how much importance to attach to an issue or topic from the emphasis the mass media placed upon it".}

This theory reflects that through the media, positive or negative reputation can be created for individual, government policies and programmes based on what the media publishes or broadcast. 
Also, a negative reputation can be converted to a positive one through the media publication and vice-versa as such brown envelope syndrome could have implication for journalists in the performance of their daily activities.

\section{Dependency Theory}

This theory states that the mass media are crucial to our society and that we depend on them for certain social functions. It is derived from a functionalist view of society and proposes that we depend on the media for information about our environment for the transmission of cultural values, and for identification and interpretation of key social issues. Sandra Ball-Rokeach and Melvin Defleur developed this theory in 1976.

The theory is grounded on classical, sociological literature positing that media and their audiences' should be studied in the context of the larger social system. Secondly, the theory ties together the interrelationships of broad social system, mass media, and the individual into a comprehensive explanation of media effects. As its core, the basic dependency hypothesis states that the more a person depends on media to meet needs, the more important media will be in a person's life and therefore the more effects the media will be on a person. According to Sandra Ball - Rokeach and Melin Defleur (2010 pp116-118) Dependency on media emerges from three relationships:

- The relationship between the society and the media: Within this relationship, media access and availability are regarded as important antecedents to an individual's experience with the media. The nature of media dependence on societal systems varies across political, economic and cultural system.

- The relationship between the media and the audience: This relationship is the key variable in this theory because it affects how people might use a mass medium. This relationship also varies across media systems. The more salient the information needs, the stronger are the motivation to seek mediated information and the dependency on the medium. In effect, the likelihood for the media to affect audiences becomes greater.

- The relationship between the society and the audience: The societies influence customer's needs and motives for media use, and provide norms, values, knowledge and laws for their members. Social system can function as alternatives to the media by offering similar services of the media.

This theory place significant role on the media as society relies on it for information and decision making on vital social issues. Journalists can make good use of this opportunity if they act professionally on their jobs. Monetary gratifications inform of brown envelope syndrome could make journalists give biased or doctored news upon which society will form an opinion.

\section{Literature Review}

\section{Role of Mass Media}

Mass Media has a prominent role to play in modern society because it can bring about radical changes and improve social evaluation with greater influence on our civil, social, cultural, political, economic and aesthetic outlook. The press is seen as the fourth estate of the realm acting as a watchdog, a kind of shepherd that fixes its glittering eyes on other arms of government to ensure that they do not abuse their powers (Ndolo 2011).

Mass media as seen by many as the most powerful institution especially in a democratic government where freedom of expression and independence of the press occupy an enviable position Agbanu (2011). Defleur (2010) remarks that the press called the attention of the people to the transgression of those in position of powers by "Speaking against the Crown during the struggle for independence as many of the writers no doubt paid the price, they did go to jail".

MacBride (1980) argued that nothing has influenced the lives of modern man as the mass media. Thus, according to him, modern society is nearly unimaginable without the mass media, as 
mass media has a direct effect on modern culture. Society controls mass media and vice - versa. Media ownership and control affect media content, which in turn determines media effects (Ndolo, 2005).

\section{Hate Speech}

Hate speech is defined as any speech that is used to demean persons based on their identifiers such as race, gender, sexuality and ethnicity and predispose them to act of violence (Adelakun, 2017). Miabore (2010) cited by Adisa et al (2017) observe that some media houses are geared up by Brown Envelope Syndrome to motivate or promote hate speech as an antecedent to support their own people in the society. Malik (2005) lends credence to Miabore remarks by affirming that due to Brown Envelope Syndrome, the media has not performed its stewardship function through reportage of events and crisis situations in relation to social responsibility theory of the press which emphasized that the media must keep up with the professional standard of truth, objectivity, accuracy and impartiality in order not to further aggravate the fake news or hate speech syndrome.

Fasakin et al (2017) have pointed accusing fingers at some of the media houses averring that the media to some extent have promoted fake news, hate speeches, violence, civil disorder and biases in favour of one minority group while relegating the views of other minor or major group to the background because of brown envelope syndrome. Hate speeches are aimed to lower personal esteem of people either as a group or as individuals and even malevolent wishes against political leaders.

Tenuche (2009) posits that political behaviour is filled with hate speeches and abusive languages by both the contestants and the electorates. Many scholars and electoral observers have noted that hate speech is always prevalence during election periods in Nigeria. Politicians always throw jabs at one another through the mass media and many derogatory comments were always made against opposition political parties and candidates. Yakubu and Ali (2017) noted that former President of Nigeria, Chief Olusegun Obasanjo was reported to have said that election is war in Nigeria and you must win by all means. During the 2015 elections, Dame Patience Jonathan, Asari Dokubo, PDP and APC, Muhammadu Buhari, Ayodele Fayose and the host of others were reported by different media to have used indicting, derogatory and abusive languages against the opposition parties and their candidates. The politicians are not the only one involved in this act. The people through their social media platforms use abusive words against politicians, political parties, party supporters and people from other tribes and religion.

\section{Fake News}

Fake news can be seen as a form of yellow journalism consisting mainly of propaganda with intention to give false information or hoaxes through print, broadcast or online/social media. Fake news is seen as a threat to our democracy and it has been used by politicians and the elite class to mislead members of the public on issues of national importance. Fake news is made up of stuffs carefully manipulated to look like credible news reports and are spread online to large audiences who may believe the story and spread it to other members of the public. Fake news gained considerable attention in the 2016 elections of the United States of America where the two dominant parties were blaming one another for spreading of fake news. Many US citizens believed that widespread proliferation of fake news helped influence the results of the elections. Facebook recently announced that it would put up more stringent controls over paid advertisements and also flag stories of 'questionable legitimacy' with an alert notifying readers that the content has been disputed by third party fact checkers.

Recently in Nigeria, there was a fake news that our President died sometimes ago in United Kingdom hospital after a protracted illness and that the person who is acting as the President is one Jibrin from Sudan. The news claimed that the President was cloned and that the person who is now acting as the President was not the person we voted for. The Presidency had responded to the fake news warning perpetrators to desist from it. In similar direction, members of the opposition parties accused the Independent National Electoral Commission (INEC) to have secretly established 3000 
polling units in the North Eastern part of Nigeria with a view to rigging the elections in favour of the ruling 'All Progressive Congress' (APC). The INEC Chairman had come out to debunk the story. All these were capable of causing problems in the country where politics thrive on religion, fake news, hate speech and tribalism to cause disunity among the electorates.

Fake news and hate speech have been banned by the Federal Ministry of Information and National Orientation with stiffer penalties meant for the perpetrators. The Minister of Information had on several occasions warned on the use of hate speech and fake news by members of the political class. The Nigerian Television Authority (NTA) and Radio Nigeria are also mounting regular campaigns against fake news and hate speech because of the damages it may cause on our electoral process, unity and national development.

\section{Gratification and Media Practice}

The National Broadcasting Commission (NBC) and the Nigerian Union of Journalism (NUJ) hardly feature a session during which reference was not made of the influence of gratification in the practice of Journalism. Gratification thwarts creativity as it generates antagonistic relationships between the media practitioners and members of the public. Nwabueze (2005) worked on the perception of Nigerian Journalists about brown envelope syndrome and the need for ethical reorientation. The study was aimed at finding out from practicing journalists what their perception of the brown envelope syndrome is. The findings showed that the basic aim behind the continued existence of the syndrome in journalism is the orientation of journalists. According to the study, most journalists see nothing wrong with the acceptance of brown envelopes.

In a related study, Okoro and Ugwuanyi (2006) conducted a study on brown envelope syndrome and mass media objectivity in Nigeria. In the study, they sought to find out if journalists in Nigeria accept brown envelopes and if such action affects journalists' social responsibility and objectivity in reporting. Findings from the study revealed that journalists in Nigeria accept brown envelopes because of poor conditions of service and lack of adherence to ethical standards. They found out that such actions affect mass media objectivity negatively. Their study recommended among others that the Nigerian Union of Journalists (NUJ) and other relevant agencies should ensure strict application and compliance to professional ethics and standards by practicing journalists. Ekeanyanwu and Obaianigwe (2010) did a similar study on the perception of Lagos - based journalists on brown envelope syndrome in the coverage of news and events in Nigeria. Their study confirmed like other similar studies that brown envelope syndrome exists and the issues have become institutionalized within the Nigerian media circles.

According to the study, various reasons ranging from poor remunerations, lack of good welfare packages for journalists in the industry from government and media proprietors, lack of interest in the industry were given as justifiable excuses. They recommended that after the establishment of a healthy/competitive rewards system and welfare packages, the existing code of journalistic practice should be strengthened to tackle the menace.

Okoro and Ugwuanyi (2006) agree with this position in similar argument but note that enforcement remains the missing link in earlier efforts to eradicate the problem. This code has been in existence for more than a decade yet brown envelope syndrome is still in existence in the practice of journalism in Nigeria. Enforcement of the various codes of ethics that preach professionalism is the only way to ensure ethical conduct and behaviour amongst journalists and other categories of media practitioners (Ekeanyanwu and Obaianigwe, 2010)

Adaba (2001) believes that education and training should make room for sound ethical behaviour on media practice. In a similar view, Ukozor (2002) opines that ethics should cause the journalists actions to be right or wrong, good or bad, responsible or irresponsible that journalists today need to know their limitations through training to avoid unethical practices that abuse of power of the media in society could cause. Ukozor (op cit) further notes that if media is properly used, it could wipe out dictatorship, make civil war unnecessary, enforce social justice, promote equal rights and make democracy more successful in a communal society and further to this, the 
mass media must give people equal opportunity to participate in matters affecting them, and that few people should not be allowed to influence the media.

Gratifications in any form could erode the respect and confidence the society has in media practitioners. Nworgu and Nwammuo (2007) attributed gratification practices to lack of resources leading to some professional misconduct. They further noted that investigative journalism is absent in the Press these days, because, the professional enthusiasm is no longer as readily available in the job as it is used to be in the past.

Nwosu (1990) protests against unnecessary inducements when he notes that:

"It would be superfluous to restate that responsible people are dissatisfied with negative gratification. The directorial argument portrays that the country has enough problems and wonder why communicators (supposedly people) should add to the problems."

He remarks further that communication is a key factor in building or developing an organized, united and progressive nation that without it there will be no natural entity and no effective solution to natural problem and natural development.

Okunna (2001) reaffirms the very complex position of the press in society which makes its existence and survival most difficult, because the press is seen as a business enterprise. This means that as a business institution, the press must use business principles to operate in such a way that it becomes economically strong enough to defend and sustain its independence against manipulation by internal and external forces. Umechukwu (2002) posits that press as a public institution is devoted to the protection and servicing of public interest, the press must act as ear, eye and spokesman of the public. However, in the period of general economic recession, as we have it now in Nigeria, the press is faced with difficult challenges of balancing professionalism with economic recession needs. Nwodu $(2006 ; 150)$ remarks that
"Journalists are often paid meager salaries. In fact some media organizations in developing nations owe journalists salaries for several months painfully, these journalists shop in the same market with other professionals and are expected to meet both their family and social obligations, but their professional earnings cannot support these values, desires and life expectations. This is where conflict of interest comes in. media practitioners are often faced with conflict of interest when their personal values clash with their professional obligations".

Okunna (2001) asserts that lack of resources and little professional motivation have affected investigative journalism and officials and other persons in authority tend to accord less cooperation to the press during the periods of social stress than in less stressful times.

The depressed economy has contributed to the continued postponement of improvements in the salaries and other compensations for journalist especially those in government owned media houses. Suleiman (2002) remarks that;
"Some journalists faced with the burden of survival have been hard put to resist the temptation of accepting gratification that they are exposed to. The attendant consequence has been to either out rightly misrepresenting facts, close their eyes to glaring cases of illegalities or rationalize same in a bid to favour the party from which money was obtained."

Agbanu (2011) lend credence to the position of other scholars by observing that poor funding of the media houses either by government or the media house proprietors may equally encourage brown envelope syndrome. The sky rocketing price of newsprint and other operational materials have forced many media houses to close shop. Those that are still managing to survive hardly meet their obligations to the workers.

Media scholars and general public consider gratification as a cheat on the public because, this isolates the code of journalism which states that "It is the duty of journalists to refuse any reward for publishing or suppressing news or comments" (Ukozo 2002). Some media houses according to 
Suleiman (2002) have been accused of aiding and abetting corrupt practices by individual journalists. This negates the fundamental principle of fairness, equity, and balanced reporting expected from the journalism profession.

Nwabueze (2005) notes that a reporter should see himself as an autonomous professional watching the activities of government officials with a view of acting as watchdog for the society. Communication is used as an instrument to control social interaction and as such, journalists must act professionally so as to give the society necessary information upon which informed decision can be made.

\section{Materials and Methods}

Descriptive Survey method was used for the study, while the sample population comprised 100 respondents, including 50 journalists from print media and 50 journalists from electronic media and. 100 questionnaires were given out to the respondents who participated in the study. The study was carried out in Lagos State where we have the offices of all major print media houses in Nigeria as well as radio and television stations for electronic media houses.

Convenient sampling was used for data gathering. Convenient sampling is a non-probability sampling technique where subjects are selected because of their convenient accessibility and proximity to the researcher (Castillo, 2009). In total, 100 respondents were drawn from the population of journalists in print and electronic media houses operating in Lagos, Nigeria. Data collected were analysed using frequency counts, tables and percentages.

\section{Presentation and Analysis of Data}

Table 1. Frequency Distribution of Respondents Who Agreed that Journalists Accept Financial Gratification

\begin{tabular}{|l|c|c|c|}
\hline \multicolumn{1}{|c|}{ (Responses) } & $\begin{array}{c}\text { (Respondents from } \\
\text { electronic media) }\end{array}$ & $\begin{array}{c}\text { (Respondents from } \\
\text { print media) }\end{array}$ & (Percentage) \\
\hline Strongly agree & 15 & 10 & $25 \%$ \\
\hline Agree & 24 & 29 & $53 \%$ \\
\hline Strongly Disagree & 7 & 4 & $11 \%$ \\
\hline Disagree & 4 & 6 & $1 \%$ \\
\hline Undecided & 0 & 1 & $100 \%$ \\
\hline Total & 50 & 50 & $10 \%$ \\
\hline
\end{tabular}

\section{Source: Field Survey, 2019}

As indicated in table 1, 25 respondents from electronic and print media (25\%) strongly agree that journalists do accept financial gratification. In similar direction, 53 respondents from electronic media and print media (53\%) also agree that journalists accept financial gratification. 11 respondents from both print and electronic media strongly disagree that journalists do accept financial gratification. 
Table 2. Frequency Distribution of Respondents According to Reasons Why Journalists Accept Brown Envelope in Nigeria

\begin{tabular}{|l|c|c|c|}
\hline \multicolumn{1}{|c|}{ (Responses) } & $\begin{array}{c}\text { (Respondents from } \\
\text { electronic media) }\end{array}$ & $\begin{array}{c}\text { (Respondents from } \\
\text { print media) }\end{array}$ & (Percentage) \\
\hline Poor remuneration & 18 & 3 & $21 \%$ \\
\hline Poor journalistic training & 5 & 3 & $25 \%$ \\
\hline Harsh economic situation & 6 & 7 & $9 \%$ \\
\hline Corruption in the system & 7 & 2 & $14 \%$ \\
\hline Poor welfare package & 3 & 3 & $5 \%$ \\
\hline Pressure from political class & 3 & 1 & $6 \%$ \\
\hline Lack of self-worth & 2 & 2 & $3 \%$ \\
\hline Greed & 4 & 5 & $8 \%$ \\
\hline Delay in payment of salaries & 3 & 2 & $3 \%$ \\
\hline No job security & 1 & 50 & $100 \%$ \\
\hline Total & 50 & & $6 \%$ \\
\hline
\end{tabular}

\section{Source: Field Survey, 2019}

As indicated in table 2 above, 21 respondents (21\%) from both electronic and print media were of the opinion that poor remuneration was a key reason why journalists accept gratification. 25 respondents $(25 \%)$ from the electronic and print media agreed that poor journalistic training was a major cause why practitioners accept financial gratification. 14 respondents (14\%) attributed corruption in the system as a major cause why journalists accept financial gratification.

Table 3. Journalists' Perception of the Effect of Brown Envelope Syndrome on Journalistic Practice

\begin{tabular}{|l|c|c|}
\hline \multicolumn{1}{|c|}{ (Journalists' perception) } & (Frequency) & (Percentage) \\
\hline Dearth of quality journalistic practice & 14 & $14 \%$ \\
\hline Reduce public respect for practitioners & 8 & $8 \%$ \\
\hline Promote fake news & 28 & $28 \%$ \\
\hline Encourage news commercialization & 16 & $16 \%$ \\
\hline Promote hate speech & 32 & $34 \%$ \\
\hline Total & 100 & $100 \%$ \\
\hline
\end{tabular}

\section{Source: Field Survey, 2019}

As indicated in table 3 above, we can see the reaction of the journalists to the effect of brown envelope syndrome on journalistic practice. 28 respondents $(28 \%)$ believe that brown envelope syndrome encourages fake news. In similar direction, 32 respondents (34\%) agree that brown envelope syndrome encourage hate speech. 16 respondents are of the view that brown envelope syndrome encourages news communalization. 
Table 4. Distribution of Respondents (Journalists) Who Agree that Brown Envelope Influence Fake News and Hate Speech

\begin{tabular}{|l|c|c|c|}
\hline \multicolumn{1}{|c|}{ (Responses) } & $\begin{array}{c}\text { (Respondents from } \\
\text { electronic media) }\end{array}$ & $\begin{array}{c}\text { (Respondents from } \\
\text { print media) }\end{array}$ & (Percentage) \\
\hline Strongly agree & 16 & 14 & $30 \%$ \\
\hline Agree & 7 & 5 & $12 \%$ \\
\hline Strongly disagree & 25 & 23 & $48 \%$ \\
\hline Disagree & 1 & 7 & $8 \%$ \\
\hline Undecided & 1 & 1 & $2 \%$ \\
\hline Total & 50 & 50 & $100 \%$ \\
\hline
\end{tabular}

Source: Field Survey, 2019

As indicated in table 5 above, 30 respondents (30\%) from both electronic and print media strongly agree that brown envelope influence fake news and hate speech. Also, 12 respondents (12\%) from the electronic and print media agreed brown envelope influence fake news and hate speech. Fortyeight (48) respondents from both electronic and print media (48\%) disagreed that brown envelope does not influence fake news and hate speech.

Table 5. Distribution of Respondents (Journalists) According to Their Views on Which Medium Encourages Fake News and Hate Speech

\begin{tabular}{|l|c|c|c|}
\hline (Source) & $\begin{array}{c}\text { (Respondents from } \\
\text { electronic media) }\end{array}$ & $\begin{array}{c}\text { (Respondents from } \\
\text { print media) }\end{array}$ & (Percentage) \\
\hline Radio & 6 & 15 & $21 \%$ \\
\hline Television & 10 & 20 & $30 \%$ \\
\hline Newspaper & 26 & 5 & $31 \%$ \\
\hline Social Media & 8 & 10 & $18 \%$ \\
\hline Total & 50 & 50 & $100 \%$ \\
\hline
\end{tabular}

\section{Source: Field Survey, 2019}

As indicated in table 6 above, $21 \%$ of the respondents affirmed that radio encourages fake news and hate speech, $30 \%$ of the respondents agreed that television encourages fake news and hate speech, $31 \%$ of the respondents are of the view that newspaper encourages fake news and hate speech, while $18 \%$ of the respondents are of the view that social media encourages fake news and hate speech.

\section{Discussion of Findings}

In solving the problem statement of this research, three research questions were drawn. A-5 questionnaire items was drawn from these research questions in order to get data from the specific population used for this study. The data gotten from the respondents are presented in Tables 1 to 6 above. It is from these data the researcher provided answers to each research question in relation to literature and the theories used for this study. 


\section{Research Question One: What are the causes of brown envelope syndrome in Nigeria?}

From the data gotten it was revealed that $21 \%$ of the respondents were of the opinion that the reason Journalists accept brown envelope in Nigeria is poor remuneration, 25\% of the respondents said poor journalistic training, (9\%) of the respondents agreed harsh economic situation, $14 \%$ of the respondents said corruption in the system, $5 \%$ of the respondents affirm poor welfare package, $6 \%$ of the respondents believe pressure from political class, $3 \%$ of the respondents said lack of selfworth, $6 \%$ of the respondents affirm greed, $8 \%$ of the respondents said delay in payment of salaries, while $3 \%$ of the respondents agreed no job security in Nigeria are the causes for brown envelope syndrome in Nigeria

Thus, it can be said that poor remuneration, poor journalistic training, harsh economic situation, corruption in the system, poor welfare package, pressure from political class, lack of self-worth, greed, late payment of salaries, no job security are causes of brown envelope syndrome in Nigeria. The above findings are supported with the work of (Okiri and Ugwa (2006) when they asserted that in developing countries like Nigeria, poverty debases human dignity and diminishes scale of honour. Love of money through gratification to influence news as opposed to editor's sense of value is the order of the day and shortcomings may force journalists to engage in some unethical practices such as sensationalism, yellow journalism, hate speech, fake news, invasion of privacy. Also the study by Ekeanyanwu and Obaianigwe (2010) supported the findings when they opined that journalists in Nigeria accept brown envelopes because of poor conditions of service and lack of adherence to ethical standards which such actions affect mass media objectivity negatively.

\section{Research Question Two: What are the perceptions of Journalists on impact of brown envelope syndrome on journalistic practice in Nigeria?}

From the data gotten it was revealed that $34 \%$ of the respondents agreed that brown envelope syndrome encourages hate speech, $28 \%$ of the respondents agreed that brown envelope syndrome encourage fake news, $16 \%$ of the respondents of are of the view that brown envelope syndrome encourage news commercialization, $14 \%$ of the respondents agreed that brown envelope syndrome is dearth of quality journalistic practice, while $8 \%$ of the respondents agreed that brown envelope syndrome reduce public respect for practitioners

Thus it can be said that brown envelope syndrome encourages hate speech, fake news and news commercialization. The above findings are supported with the work of Adisa et al (2017) who observed that some media houses are geared up by Brown Envelope Syndrome to motivate or promote hate speech as an antecedent to support their own people in the society. Also the work of Fasakin et al (2017) who have pointed accusing fingers at some of the media houses averring that the media to some extent have promoted fake news, hate speeches, violence, civil disorder and biases in favour of one minority group while relegating the views of other minor or major group to the background because of brown envelope syndrome.

\section{Research Question Three: What are the impacts of brown envelope syndrome on hate speech and fake news?}

From the data gotten it was revealed that $53 \%$ of the respondents agreed that journalists accept financial gratification, $25 \%$ of the respondents strongly agreed that journalists accept financial gratification, $48 \%$ of the respondents agreed that brown envelope influence fake news and hate speech, $48 \%$ of the respondents strongly agreed that brown envelope syndrome influence fake news and hate speech, $82 \%$ of the respondents agree that television, radio and newspaper encourages fake news and hate speech more than the radio medium.

Thus it can be said that journalists accept financial gratification, brown envelope syndrome influence fake news and hate speech. Television and newspaper encourages fake news and hate speech more than the radio medium. the findings above are supported with the work of Okoro and Ugwuanyi (2006) lend credence to the fact that brown envelope syndrome encourages hate speech and fake news when they affirm that journalists in Nigeria accept brown envelopes because of poor 
conditions of service and lack of adherence to ethical standards. Also the work of Nworgu and Nwammuo (2007) when they stated that Gratifications in any form could erode the respect and confidence the society has in media practitioners.

\section{Conclusion}

The paper concludes that poor remuneration, poor journalistic training, harsh economic situation, corruption in the system, poor welfare package, pressure from political class, lack of self-worth, greed, late payment of salaries, no job security are causes of brown envelope syndrome in Nigeria. Brown envelope syndrome encourages hate speech, fake news and news commercialization. Journalists accept financial gratification, as brown envelope syndrome influence fake news and hate speech. Television and newspaper encourages fake news and hate speech more than the radio medium.

\section{Recommendations}

Having analysed, discussed and interpreted the data collected in this paper, the researchers therefore recommend the following;

1.This study recommends prompt payment of salaries and special salary scale, training should be organised for journalists as antidotes against brown envelope syndrome.

2. Apart from severe punishment to be meted out to erring journalists who may involve themselves in hate speech or fake news, the media house(s) that such journalist(s) represent should also be sanctioned. This will encourage healthy professional practices among the serving journalists in Nigeria.

3. Media practitioners should be guided by the appropriate code of ethics guiding their profession and pre-empting bad journalistic practices which find expressions in fake news and hate speeches

\section{References}

[1] Adaba, T. (2001). Selling news on Air. In Lanre Idowu (ed) watching the watchdog. Media Review. Lagos: Diamond Publishers Ltd.

[2] Adelakun, A. (2017). Opinion. Published in Punch Newspaper edition of August 31, 2017.

[3] Adesanoye, F. A. (1990). Mass Communication and Nigerian's Development. In Ikechukwu Nwosu (Ed.). Aba: Frontier Publishers Ltd

[4] Adisa, R., Patrick, U., Abubakar, I. and La'aro, O. (2017). Media, Politics and hate speech: A critical discourse analysis. Academia journal. 6 (1) $240-252$.

[5] Agbanu V.N (2011). Re-examining Brown Envelope and news commercialization syndrome: A case for Redefined news, Judgment and Media Ethics. In E.McCarty Mojaye (ed) Journal of Communication and Media Research vol 3. No 2. Abraka: Delmas Publications

[6] Ahshull, H. (1984). Agent of Power. New York: Longman Incorporated

[7] Alade, A. (2019, March).. The Media, Fake News, Hate Speech and the Nigerian Society. Ibadan, Oyo State, Nigeria: Lead City University

[8] Baran, S.J. (1999). Introduction to Mass Media, Media Literary and Culture. California: Mayfield Publishing Company

[9] Baran, S.J. (2007). Mass Communication Media, Literacy and Culture Fourth Edition. McGraw Hill Publishers. 
[10] Carrington, $\mathrm{T}$ and nelson $\mathrm{m}$ (2002). Media in transition: the hegemony of economics. In the right to tell; The role of mass media in economic development Washington dc: the world bank pp $225-245$.

[11] Defleur, M. T (2010). Mass Communication Theories: Explaining Origin, process and effects. New York; Allyn and Bacon.

[12] Fasakin, D., Oyero, S., Okorie, N. and Oyesomi, K. (2017). Hate speech and the 2015 general elections in Nigeria. International Journal of advances in Social Sciences. 3 (9) $948-953$.

[13] Folarin, A.B (2005). Theories of mass communication: an introductory text. Lagos: Bakinfol Publishers.

[14] Lasswell, H. (1927). Propaganda Technique in the World War. New York: Smith Press

[15] Mac Bride, S. (1980). Many Voices, on World: Communication and Society Today and Tomorrow. Paris: UNESCO Publishing Company

[16] Malik, S. (2015). When hate speech crosses the borderline of freedom of expression. International centre for investigative reporting. Retrieved from www.icirnigeria.org/whenhatespeechcrossestheborderlineoffreedomofexpression

[17] Ndolo I.S (2005). Mass Media System and society. Enugu: Rhyce Kerex Publishers.

[18] Ndolo I.S (2011). Media as the fourth estate of the realm. Real or Imagined ?" In Ike S

[19] Nwabueze C.D (2005). The art of Investigative Reporting: A Practical guide. Enugu: Daisy Press

[20] Nwabueze, N. (2012). Press Release Welfare Cameroon.

[21] Nwodu, L.C (2006). Journalism practice: news, aesthetics, ethics and laws. Enugu: Rhyce Kerex Publishers.

[22] Nworgu K.O and Nwammuo A.N (2007). Value system and Journalistic decision making: the role of ethical reasoning in mass media practice. International Journal of Communication no 6 pp345-358

[23] Nwosu I.E (1990). The new journalism for the new Nigeria. In Ikechukwu Nwosu (ed). Mass Communication. Enugu: Frontier Publishers

[24] Ojebode, A. (2018). Fake news, hate speech and the 2019 general elections - the redemptive role of the nigerian media. The text of the 13 th Annual Federal Radio Corporation of Nigeria (FRCN). FRCN Annual Lecture. Abuja: FRCN

[25] Okoro, N.M. and Ugwu Anyi. J.C. (2006). Brown Envelope Syndrome and Mass Media Objectivity in Nigeria. African Journal of Communication and Development. 1 (1) 123 148

[26] Okunna, S. (2001). The Critical Journalist as the Bastion of Democracy. In Nwosu(Ed) the Nigerian Journal of Communication Vol 1. (2001). Enugu: Rhyce Kerex Publishers

[27] Sulaimann, J. (2002). Key issues in Nigeria journalism. Lagos: Busprint Division of Busola Ogunyale and Co.

[28] Tenuche, M. (2009). The language of politics and political behaviours: "Rhetoric of president Olusegun Obasanjo and the 2007 general elections in Nigeria". Journal of Public Administration and Policy Research

[29] Ukozo, F. (2002). Media Laws and Ethics. Enugu: John Jacobs Classic Publishers.

[30] Umechukwu, P. (2000). Topical Issues in the mass media and democratic Nigeria Society. Enugu: Talladu Publishing Company 